\author{
Wasyl Kyfyak \\ Uniwersytet w Kijowie \\ Czerniowiecki Instytut Handlowo-Ekonomiczny \\ tourbuc@ukr.net \\ Aleksander Kyfyak \\ Czerniowiecki Uniwersytet Jurija Fedkowicza \\ alkyfyak@bigmir.net
}

\title{
METODYKA OBLICZANIA WSKAŹNIKÓW INDYWIDUALNEJ AKTYWNOŚCI TURYSTYCZNEJ
}

\begin{abstract}
Abstrakt: Celem autorów artykułu jest prezentacja współczesnych metod określania występujących cech ruchu turystycznego oraz wartości towarzyszących mu usług turystycznych i dóbr nabywanych przez turystów, obliczania liczby turystów odwiedzających dane miasto oraz prognozowania rozwoju turystyki. Cele postawione $\mathrm{w}$ artykule realizowane są za pomocą następujących metod ogólnych i szczegółowych: analiza i synteza, systematyzacja i generalizacja, ocena ekspercka i ekstrapolacja. Na przykładzie ukraińskiego miasta Czerniowce ustalono liczbę turystów odwiedzających miasto, jak również rodzaje dostępnych usług oraz średnie roczne tempo wzrostu sprzedaży usług turystycznych w ciągu ostatnich pięciu lat, co pozwala przewidzieć podaż usług w nadchodzącym okresie.
\end{abstract}

Słowa kluczowe: kalkulacja, usługi typowe i towarzyszące, rodzaje i wartość usług, liczba turystów, wdrażanie, tempo wzrostu, prognozowanie.

\section{WSTĘP}

Rozwój turystyki jako sektora gospodarczego charakteryzują liczne wskaźniki, określające zasoby turystyczne, aktywność finansową i gospodarczą oraz jej skuteczność, wpływ na rozwój miast, gospodarkę regionalną i krajową, jak również monitorujące rynek turystyczny.

Przykład Ukrainy, a konkretnie miasta Czerniowce, posłuży obliczeniu poszczególnych wskaźników określających wartość usług turystycznych, wielkość ruchu turystycznego, dostępność zasobów turystycznych oraz wpływ turystyki na rozwój społeczno-gospodarczy. W artykule zostanie również przedstawione średnie roczne tempo wzrostu sprzedaży usług turystycznych oraz prognozowana wartość usług sprzedawanych w przyszłości.

\section{OKREŚLENIE PROBLEMU}

Ukraina, dysponująca unikatowymi zasobami rekreacyjnymi i turystycznymi, posiada ogromny potencjał w zakresie turystyki zagranicznej i krajowej. „Całko- wita powierzchnia terenów naturalnych nadających się do celów turystycznych i rekreacyjnych wynosi 9,4 mln ha, które nie zostały jeszcze w pełni zagospodarowane. $\mathrm{Na}$ terytorium naszego kraju występuje ponad 125 tys. zabytków archeologicznych, architektonicznych, miejskich, historycznych i artystycznych, jak również setki muzeów" (KYFYAK 1995).

Pomimo konfliktów we wschodniej części kraju oraz innych problemów gospodarczych i społecznych, Ukrainę można zaliczyć do grupy krajów wiodących pod względem liczby turystów zagranicznych. Według biura prasowego Administracji Straży Granicznej Ukrainy, biorąc pod uwagę tylko 10 krajów, których obywatele najczęściej przekraczają granicę Ukrainy, w 2017 r. liczba odwiedzających wzrosła do prawie $13 \mathrm{mln}^{1}$. Zdaniem ekspertów turystyka ukraińska jest w stanie uzupełnić roczny budżet państwowy i budżety lokalne o dziesiątki miliardów hrywien, wytwarzając do $10 \%$ rocznego dochodu budżetowego, nie licząc efektu mnożnikowego powiązanych z nią sfer ekonomicznych.

Jednocześnie, według statystyk, następuje spadek sprzedaży usług turystycznych, co jest sprzeczne ze 
wzrostem wewnątrzkrajowego ruchu turystycznego i rozwojem infrastruktury turystycznej. Wskazuje to na brak uwzględnienia wydatków ponoszonych przez turystów oraz wartości usług turystycznych, oferowanych na czarnym rynku.

Konieczność rozwijania i wdrażania nowoczesnych metod obliczania wartości usług turystycznych i produktów nabywanych przez turystów dla danego okresu oraz wielkości ruchu turystycznego stanowi o istotności badań naukowych, które pomogą ustalić rzeczywisty wpływ turystyki na rozwój gospodarczy regionu lub miasta, określający ekonomiczną i społeczną rolę turystyki pośród innych gałęzi gospodarki oraz rozwoju związanych z nią strategii.

\section{ANALIZA NAJNOWSZYCH BADAŃ}

Prace naukowe wielu zagranicznych i krajowych badaczy poświęcone są zagadnieniom terytorialnej organizacji aktywności turystycznej i określeniu jej wpływu na rozwój regionu lub miasta oraz powstawanie nowych szlaków. Publikacje te dotyczą również organizacji Tourist Accounts, obserwacji statystycznych oraz metod obliczania wartości wykorzystanych usług turystycznych. Polscy badacze - A. STASIAK, J. ŚLEDZIŃSKA i B. WŁODARCZYK (2014) - w pracy zatytułowanej Szlaki turystyczne. Od planu do realizacji określają znaczenie rozwoju nowych szlaków turystycznych i ich rolę w kształtowaniu ruchu turystycznego. W publikacji Miasto i turyzm, odwołując się do przykładu Łodzi (Polska), S. LISZEWSKI (2017) opisuje główne związki przyczynowo-skutkowe pomiędzy funkcjami miasta a strukturą ruchu turystycznego, który ma znaczący wpływ na społeczno-gospodarczy rozwój miasta. W monografii Rynki turystyczne specjaliści bułgarscy S. Rakadzhieska i S. Marinow prezentują swoje spojrzenie na główne cechy jakościowe rynku turystycznego, uwzględniając wskaźniki ilościowe (RAKADZHIESKA, MARINOW 2005). Aby przeanalizować dane dotyczące rozwoju turystyki regionalnej oraz wskazać rodzaje usług zapewnianych turystom, jak również liczbę turystów, zastosowano metodę analizy shift-share, opisanej w opracowaniu pt. Analiza dynamiki przemystu turystycznego w Brazylii: wyzwania i zalecenia, autorstwa F. Sobral z Portugalii oraz A. Peci i G. Souza z Brazylii (SOBRAL, PECI, SouzA 2007). Na przykładzie pomiarów i analizy wzrostu liczby turystów przybywających do Ameryki Południowej metoda ta pozwoliła nie tylko określić ich liczbę, ale również wyjaśnić zachowania turystów i głębiej zdiagnozować dynamikę sektora turystycznego w danym okresie. Naukowcy ukraińscy - W. Krawtsiw, W. Ewdokimenko, P. Gudz, W. Tsybukh, O. Milaszko, W. Herasymienko, W. Pawlotsky - i inni uważają, że sektor tury- styczny ma znaczący wpływ na rozwój ogólnej i specjalistycznej infrastruktury regionu, jest podstawowym źródłem dochodu w dewizach i sprzyja rozwojowi powiązanych rodzajów aktywności. Zwłaszcza W. Tsybukh twierdzi, że zapewnienie usług turystycznych i nabywanie produktów skojarzonych aktywnie wspiera funkcjonowanie i rozwój dużej liczby przedsiębiorstw skupionych $\mathrm{w}$ regionie. $\mathrm{W}$ ramach sektora turystycznego funkcjonuje ponad 40 sfer gospodarczych: od działalności rolniczo-przemysłowej, której zadaniem jest nakarmienie gości, do pracy agencji porządku publicznego, zapewniających ład i bezpieczeństwo (TsYBUKH 2004). Jednakże obliczenia liczby turystów i wartości usług turystycznych przeprowadzane są tylko przez przedsiębiorstwa turystyczne, które te usługi dostarczają. Badania statystyczne i obliczanie wartości usług turystycznych „przeprowadzane są w celu określenia, jak turystyka wpływa na gospodarkę kraju i bilans płatniczy, jak również zidentyfikowania głównych trendów w rozwoju turystyki, jeśli chodzi o planowanie bazy materialnej i technicznej, przeprowadzanie badań marketingowych i promocji produktów" (MILASzKO 2010). Charakteryzując rynki turystyczne, V. Herasymenko i V. Pawlotsky określają pojemność rynku regionalnego i proponują metodologię ustalania ilościowych wskaźników rynku regionalnych usług turystycznych (HERASYMIENKO, PAWLOTSKY 2011). Równie ważne są podejścia naukowe do określania wartości usług turystycznych i obliczania liczby turystów w Euroregionie Upper Prut (KYFYAK 2008).

Wiadomo, że obecnie żaden kraj na świecie nie monitoruje systematycznie turystyki jako całości, ale według raportu WTO wiele państw nie dostarczyło żadnych informacji o turystyce międzynarodowej. Zatem ustalanie wartości usług turystycznych dla danego okresu oraz przewidywanie jej w przyszłości jest ważne zarówno dla pojedynczych regionów, jak i dla całego kraju.

\section{PREZENTACJA GLÓWNEGO MATERIAŁU BADAŃ}

Określenie rodzajów i oszacowanie wartości usług turystycznych i dóbr zakupionych przez turystów na danym obszarze, prognoza popytu na usługi turystyczne oraz określenie miejsca i roli turystyki w społeczno-gospodarczym rozwoju danego miasta lub regionu, jak również wpływu turystyki na całość gospodarki należą do zadań władz, instytucji naukowych, struktur przemysłu turystycznego i sektora publicznego.

Gospodarcze i społeczne znaczenie turystyki określane jest za pomocą odpowiednich wskaźników, specjalnie do tego celu wyliczonych. W Państwowej kla- 
syfikacji rodzajów działalności gospodarczej (PKRDG) na Ukrainie turystyka definiowana jest jako oddzielny typ działalności gospodarczej (cz. 1. „Transport i komunikacja”, punkt 63.3, podpunkt 63.30.0: „Usługi organizacji podróży”), na który składają się: działalność turystyczna, działalność pośrednicza agencji turystycznych, mająca na celu wprowadzenie produktu turystycznego touroperatorów, działalność przewodników (turystów), sprzedaż i rezerwacja biletów na różne rodzaje wyjazdów (wakacje, wyjazdy służbowe etc.) wszystkimi środkami transportu². Funkcjonowanie sanatoriów i ośrodków wypoczynkowych, hoteli, restauracji, ośrodków turystycznych, transportu turystycznego i pozostałych usług tego typu znajduje się w innych częściach PKRDG, co znacząco komplikuje określenie ogólnej roli gospodarczej przemysłu turystycznego.

Współcześnie wpływ turyzmu na gospodarkę narodową, gospodarkę regionu lub miasta jest nieprecyzyjnie określony, ponieważ uwzględniając całkowitą wartość dóbr i usług, jak również rozważając ją oddzielnie dla każdej gałęzi przemysłu, nie można ustalić udziału, jaki mają produkty i usługi nabywane przez turystów oraz oferowane wyłącznie poprzez działalność turystyczną. Występuje tu też zależność od płatności dokonywanych przez turystów gotówką. Praktycznie niemożliwe jest wyodrębnienie towarów i usług sprzedawanych turystom (np. wartość produktów spożywczych, które nabywają, lub usług transportowych) z całej sprzedaży. Zatem kwestia metodologii obliczania liczby turystów odwiedzających dany obszar i wartości zapewnianych im usług wymaga szukania dalszych rozwiązań.

Opierając się na przykładzie Czerniowców, zaproponowano różne podejścia do obliczania typowych i towarzyszących usług turystycznych oraz towarów kupowanych przez turystów.

Aby obliczyć wartość usług turystycznych i towarów zakupionych na terenie miasta Czerniowce w roku 2017, jak również określić ich wartość, wykorzystano następujące źródła informacji:

- dane Regionalnego Urzędu Podatkowego w Czerniowcach,

- statystyki państwowe,

- dane administracyjne,

- indywidualne dodatkowe opracowania statystyczne,

- oceny eksperckie.

Badanie obejmujące 2370 turystów pozwoliło ustalić listę i szacunkowy koszt typowych towarów i usług, z których turyści korzystali w trakcie pobytu w Czerniowcach.

Obliczenia uwzględniały wydatki ludzi odwiedzających to miasto, niezależnie od celu podróży, ponieważ każda taka osoba wydała jakieś pieniądze podczas pobytu w mieście, korzystając z dóbr i usług w różnych sektorach gospodarki, co wpływa na całą gospodarczą i społeczną sferę życia miasta.

Lista typowych i nietypowych usług oraz produktów turystycznych, wykorzystywanych przez turystów na obszarze miasta Czerniowce w ciągu 2017 r. zawiera (wg PKPiU Ukrainy):

- usługi hotelowe i restauracje;

- usługi gastronomiczne;

- serwowanie napojów podczas programów rozrywkowych;

- usługi komunikacyjne/transportowe;

- autokary wycieczkowe;

- wycieczki z przewodnikiem;

- usługi operatorów wycieczek i biur podróży;

- usługi wypoczynkowe, rozrywkowe, kulturalne i sportowe;

- muzea i inne obiekty kulturalno-historyczne;

- usługi finansowe i ubezpieczeniowe;

- inne usługi (handel, informacja, doradztwo, usługi fotograficzne, tłumaczenia itd.).

Wyniki badań pokazują, że 22\% turystów odwiedzających Czerniowce podróżowało indywidualnie, a pozostała część - ze znajomymi, rodziną albo w grupie turystycznej.

Stosując metody obliczania wielkości ruchu turystycznego, zaakceptowane we wspólnym rozporządzeniu z 12 listopada 2003 r. (nr \#142/394), wydanym przez Państwową Administrację Turystyki na Ukrainie oraz Państwowy Komitet Statystyczny Ukrainy33, jak również wykorzystując uogólnione dane pochodzące z badań dotyczących struktury i kosztów usług w 2017 r., ustalono, że turyści zagraniczni oraz przybywający z innych regionów Ukrainy, którzy odwiedzali Czerniowce w 2017 r., wydawali przeciętnie 1645 hrywien ukraińskich (UAH) lub 52 euro dziennie. Według Wydziału Turystyki przy Urzędzie Miasta Lwów średnia dzienna suma wydawana przez turystę przebywającego we Lwowie wynosiła $2355 \mathrm{UAH}$ lub 75 euro $^{4}$.

Ustalono, że przeciętny okres pobytu jednego turysty w Czerniowcach to 1,4 dnia, zatem pojedynczy turysta wydał średnio 2303 UAH podczas wizyty w mieście.

Zgodnie z uzyskanymi wynikami badań dzienne wydatki turystów mieszkających w hotelach $\mathrm{w}$ mieście kształtowały się następująco:

1) przeciętny koszt zakwaterowania i wyżywienia - 928 UAH;

2) usługi touroperatorów i biur podróży, wydatki na transport, wycieczki, rozrywkę - $541 \mathrm{UAH}$;

3) zakup pamiątek, produktów towarzyszących oraz inne wydatki - $176 \mathrm{UAH}$.

Według Regionalnego Państwowego Urzędu Skarbowego w Czerniowcach w 2017 r. same opłaty turystyczne wnoszone przez turystów w hotelach zasiliły budżet miasta o 258,2 tys. UAH, co stanowi 71,4 tys. 
UAH lub 27,6\% więcej niż w poprzednim roku ${ }^{5}$. Całkowita wartość usług związanych z zakwaterowaniem wzrosła do 25,8 mln UAH, co wskazuje, że 11211 turystów mieszkało w hotelach, które wnoszą opłatę turystyczną.

Ogólnie rzecz biorąc, zgodnie z wyliczeniami opartymi na wspomnianej wcześniej metodologii oraz przeprowadzonych badaniach, całkowita wartość usług, z których skorzystali turyści, oraz produktów, które zakupili w Czerniowcach w 2017 r., wynosiła około $720 \mathrm{mln}$ UAH. Dla porównania we Lwowie suma ta dla tego samego okresu wyniosła prawie 19 mld UAH lub 615 mln euro6, czyli była 26,3 razy większa niż w przypadku Czerniowców.

Według wyliczeń liczba turystów $\left(Q_{t}\right)$, którzy odwiedzili Czerniowce w 2017 r., wynosi:

$$
\begin{aligned}
& Q_{t}=A / s \cdot(A / d \times L / s)=720000000 \text { UAH: } \\
& (\text { UAH } 1645 \times 1,4 \text { dzień })=312635 \text { osób. }
\end{aligned}
$$

Dla porównania dane Wydziału Turystyki w Urzędzie Miasta Lwowa w 2017 r. dla Lwowa wskazują, że odwiedziło go 2,6 mln turystów, przebywających tam średnio przez 4,4 dnia 7 .

Jeśli rozważymy koszty turystyczne schematycznie, to okaże się, że główne wydatki to opłaty za hotel, restauracje i przedsiębiorstwa turystyczne, które bezpośrednio zapewniają usługi. Część tych sum pochodzi z importowanych towarów i usług nabywanych w miejscu pobytu. Nie odgrywają one innej roli w działalności gospodarczej miasta. Pozostałe kwoty są przeznaczane na zakup lokalnych produktów i usług oraz pokrycie kosztów energii, wynagrodzeń, podatków itd. W każdym cyklu kosztów część funduszy kumuluje się, a część jest wydawana w formie podatków i przestaje cyrkulować w gospodarce danego terytorium.

Przeprowadzone badania pokazują również, że 345 UAH dziennie lub 21\% całkowitych dziennych wydatków zostało poniesionych przez turystów w Czerniowcach na dodatkowe usługi, pamiątki, transport etc.

Lista typowych produktów i usług, z których korzystali turyści w 2017 r., jak również ich wartość potwierdzają, że turystyka bezpośrednio i pośrednio poprzez konsumpcję wywiera stymulujący wpływ na rozwój takich rodzajów aktywności gospodarczej, jak: transport, hotelarstwo i restauracje, handel detaliczny, przemysł spożywczy, budownictwo, komunikacja, ubezpieczenia, pośrednictwo finansowe, rekreacja i rozrywka, kultura, sport itd. Rozwój turystyki pobudza lokalną gospodarkę i stymuluje tworzenie dodatkowych stałych lub sezonowych miejsc pracy. Konsumpcja turystyczna aktywnie wspiera produkcję pamiątek, rzemiosło ludowe, narodowe dziedzictwo kulturowe i inne.

Dzięki corocznej analizie wprowadzania usług i dóbr turystycznych w mieści Czerniowce, przeprowa- dzanej w ciągu ostatnich pięciu lat (2012-2016), oraz ustaleniu licznych czynników wpływających na realizację usług turystycznych możliwe jest przewidzenie przyszłego popytu na usługi związane z podróżowaniem (za 3-5 lat).

Przy zastosowaniu statystycznych metod przewidywania popytu na usługi turystyczne, które są najczęściej prognozowane, ustala się indywidualne wskaźniki prognostyczne. Statystyczne metody prognostyczne oparte są na modelach trendów (metody ekstrapolacyjne) oraz na modelach czynników, które w przeciwieństwie do metod analogii i badań eksperckich, dostarczają bardziej realistycznych danych prognostycznych.

W opinii władz miejskich Czerniowców wartość typowych produktów i usług wykorzystywanych przez turystów w tym mieście w 2012 r. wynosiła 467,9 mln $\mathrm{UAH}^{8}$, a w 2016 r. - 657,5 mln UAH ${ }^{9}$. Średnie roczne tempo wzrostu zawiera się $\mathrm{w}$ następującym wzorze:

$$
\bar{K}=\sqrt[m-1]{\frac{y_{t}}{y_{1}}}
$$

gdzie:

$\bar{K}$ - średnie roczne tempo wzrostu,

$y_{t}$ - realizacja usług $\mathrm{w}$ badanym roku (ostatnim),

$y_{1}$ - realizacja usług $\mathrm{w}$ roku wyjściowym (pierwszym),

m - liczba lat w ujęciu dynamicznym.

Według obliczeń, $\bar{K}=\sqrt[4]{\frac{657,5}{467,9}}=1,088$,

roczna wartość sprzedaży usług turystycznych w Czerniowcach w ostatnich pięciu latach (2012-2016) wzrosła przeciętnie o 8,8\% $(k)$.

Przewidywana wartość usług w przyszłym okresie:

2017 r. - 715,36 mln UAH,

2018 r. - 778,31 mln UAH,

2019 r. - 846,80 mln UAH,

2020 r. - 921,31 mln UAH.

Niezmiernie istotne jest to, że wartość usług w 2017 r. potwierdza wskaźniki prognostyczne oraz że całkowita wartość typowych produktów i usług turystycznych w Czerniowcach w 2017 r. wyniosła około 720 mln UAH.

Zatem za trzy lata konsumpcja typowych produktów i usług przez turystów w mieście Czerniowce wzrośnie do 921,31 mln UAH oraz osiągnie poziom krytyczny obciążenia infrastruktury ogólnej i turystycznej, jak również środowiska, co wymaga rozbudowy właściwej infrastruktury, sprowadzenia dodatkowych zasobów materialnych i pracowniczych oraz zachowania równowagi ekologicznej. 


\section{WNIOSKI}

Na podstawie zaprezentowanych kalkulacji określono całkowitą wartość usług i zakupionych produktów, liczbę turystów odwiedzających miasto, średnią długość pobytu i wydatki poniesione przez turystów w czasie pobytu w Czerniowcach na Ukrainie. Stosując metodę ekstrapolacji, obliczono średni roczny przyrost wartości typowych i skojarzonych usług, jak również przewidziano jego wzrost w przyszłości.

Ustalona lista usług i produktów nabywanych przez turystów potwierdza, że poprzez konsumpcje turystyka wywiera pośredni lub bezpośredni stymulujący wpływ na wiele sfer działalności gospodarczej i wymaga rozwijania odpowiedniej infrastruktury, dodatkowych zasobów materialnych i pracowniczych oraz zachowania równowagi ekologicznej.

Przewidywanie rozwoju turystyki jest częścią prognozowania rozwoju gospodarki i społecznej sfery miasta, co wymaga uwzględnienia jego cech we współczesnych warunkach. W przyszłości o głównych kierunkach rozwoju turystyki będą więc decydować czynniki społeczne, ekonomiczne i ekologiczne. Jednocześnie coraz silniejsze będzie poczucie niepewności i istnienia czynników ryzyka.

Badania naukowe i stosowanie nowoczesnych metod szacowania wartości dóbr i usług nabywanych przez turystów, np. w mieście Czerniowce, przyczynią się do ustalenia rzeczywistej wielkości ruchu turystycznego, jak również do określenia wpływu przemysłu turystycznego na gospodarkę miasta i na rozwiązywanie licznych problemów gospodarczych i społecznych.

\section{PRZYPISY}

${ }^{1}$ Naychastishe vidviduyut' Ukrayinu zhyteli Moldovy, Bilorusi ta Rosiyi [The most frequent visitors to Ukraine are residents of Moldova, Belarus and Russia] - infohrafika/ 29.01.2018; https://hromadske.ua/posts/naichastishe-vidviduiut-ukrainuzhyteli-moldovy-bilorusi-i-rosii-prykordonnyky [in Ukrainian].

2 KVED 2011 [State Classification of Types of Economic Activities in Ukraine]; http://howtoregister.com.ua/kved_2009. html.

${ }^{3}$ Pro zatverdzhennya Metodyky rozrakhunku obsyahiv turystychnoyi diyal'nosti: Nakaz Derzhavnoyi turystychnoyi administratsiyi Ukrayiny, Derzhavnoho komitetu statystyky Ukrayiny [On approval of the methodology for calculating the volume of tourism activity: Order of the State Tourism Administration of Ukraine, State Statistics Committee of Ukraine] vid 12 listopada 2003 r. № 142/394; http://search.ligazakon.ua/ 1_doc 2.nsf/link1/REG8449.html [in Ukrainian].
${ }^{4}$ U 2017 rotsi turysty zalyshyly u L'vovi ponad pivmil'yarda yevro [In 2017, tourists left over half a billion euros in Lviv]; https://espreso.tv/news/2018/01/13/u_2017_roci_turysty_za lyshyly_u_lvovi_ponad_pivmilyarda_yevro [in Ukrainian].

5 Turystychnyy zbir popovnyv skarbnytsyu Czerniowcev na mayzhe 260 tys. hrn [The tourist collection replenished the Czerniowce treasury by almost 260 thousand UAH]; https:// pogliad.ua/news/money/turistichniy-zbir-popovniv-skarb nicyu-chernivciv-na-mayzhe-260-tis-grn-349005 [in Ukrainian].

${ }^{6}$ Patrz przypis 4 .

7 Patrz przypis 4 .

8 Prohrama rozvytku turyzmu $\mathrm{v}$ misti Chernivtsyakh na 2013-2016 roky (2013). Rishennya Chernivets'koyi mis'koyi rady VI sklykannya 28.03.2013 № 793. [Tourism development programs in the city of Czerniowce for 2013-2016. Decision of the Czerniowce City Council of the VI convocation of March 28, 2013 № 793] Czerniowce [in Ukrainian].

9 Patrz przypis 4 .

\section{BIBLIOGRAFIA}

HERASYMENKO V.H., PAVLOTS'KYY V.Y., 2011, Metodyka vyznachennya kil'kisnykh pokaznykiv rehional'noho rynku turystych$n y k h$ posluh [Methodology for determining the quantitative indicators of the regional tourist services market], „Rehional'na Ekonomika"(Lviv), 2, s. 157-163 [in Ukrainian].

KYFYAK V.F., 1995, Rozvytok mizhnarodnoho turyzmu yak odyn $z$ faktoriv stanovlennya ekonomiky Ukrayiny [Development of international tourism as one of the factors of the formation of the economy of Ukraine], „Ekonomika Ukrayiny”, 7 (404) [in Ukrainian].

KYFYAK V.F., 2008, Funktsionuvannya yevrorehionu «Verkhniy Prut» ta yoho rol' $v$ intehratsiynykh protsesakh Ukrayiny [Functioning of Euroregion 'Upper Prut' and its role in the integration processes of Ukraine], "Ekonomika Ukrayiny", 6 (559) [in Ukrainian].

LISZEWSKI S., 2017, Miasto i turystyka. Wybór prac, Instytut Geografii Miast i Turyzmu Uniwersytetu Łódzkiego, Łódź.

MYLASHKO O.H., 2010, Statystyka turyzmu: Navchal'nyy posibnyk [Tourism mtatistics: textbook], Odesa, ODEU [in Ukrainian].

RAKADZHIESKA S., MARINOV S., 2005, Turisticheski pazari [Tourist markets], Varna, Izdatelska kusha STENO, 190 pp. [in Bolgarian].

SOBRAL F., PECI A., SOUZA G., 2007, An analysis of the dynamics of the tourism industry in Brazil: challenges and recommendations, „International Journal of Contemporary Hospitality Management", 19(6), s. 507-512; http://citeseerx.ist.psu.edu/ view doc $/$ download?doi=10.1.1.513.9451\&rep=rep1\&type $=$ pdf.

STASIAK A., ŚLEDZIŃSKAJ J., WŁODARCZYK B., 2014, Szlaki turystyczne. Od pomystu do realizacji, Wyd. PTTK „Kraj”, Waszawa-Łódź.

TsYBUKH V.I., 2004, Pochty bespoleznye pokazately [Almost useless indicators], „Kompan'yon”, 43, s. 36-41.

Artykuł wpłyną:

17 lutego $2018 \mathrm{r}$.

Zaakceptowano do druku:

4 maja $2018 \mathrm{r}$. 